\title{
Assessment of Tube Well Pumping Test Performance on Different Geological Formation
}

\section{Muhd Syamir Sobri ${ }^{1}$, Ahmad Khairul Abd Malik ${ }^{1 *}$, Mohd Firdaus Md Dan ${ }^{1}$, Hamzah Hussin ${ }^{2}$, Badee Alshameri ${ }^{3}$}

${ }^{1}$ Faculty of Civil Engineering and Built Environment,

Universiti Tun Hussien Onn Malaysia, 86400 Parit Raja, Batu Pahat, Johor, MALAYSIA

${ }^{2}$ Geoscience Department, Faculty of Earth Science,

University Malaysia Kelantan, 17600 Jeli, Kelantan, MALAYSIA

${ }^{3}$ National University of Sciences and Technology Pakistan, Islamabad, PAKISTAN

*Corresponding Author

DOI: https://doi.org/10.30880/jsue.2021.01.01.004

Received 24 August 2021; Accepted 11 October 2021; Available online 16 December 2021

\begin{abstract}
Water supply-demand is increasing in line with the increment in population. Natural water resources are declining due to reduction of water catchment areas, river pollution and drought. This causes the raw water quantity and quality to decrease and increase water treatment costs. Groundwater usage may be able to solve this problem due to its less polluted nature which requires less treatment. The groundwater is preserved in aquifer within the geological formations, i.e., in the alluvium and fractured-rock. However, the groundwater yield of each formation is unknown unless tube well is constructed and pumping test are performed. This study aim to evaluate the tube well performance via pumping test on two different geological formations. This research focuses on the effect of transmissivity, hydraulic conductivity, and efficiency of the aquifer, which are step-drawdown test, constant-rate test and recovery test in tube well in geological formation of alluvium and fractured rock. Three wellpumping tests at each formation were conducted at IBS Universiti Malaysia Kelantan (UMK), Kelantan, Sekolah Kebangsaan Chantum, Kelantan, Sekolah Menengah Kebangsaan Agama Tok Bachok, Kelantan, FRU Wakaf Tapai, Terengganu, Kampung Dada Kering, Kuala Lipis, Pahang, and Kampung Seri Gunung Pulai, Johor, respectively. The aquifer efficiency obtained from the relationship between transmissivity and hydraulic conductivity. The suggested value of $75 \%$ efficiency is selected to present the well's efficiency. The wells efficiency indicate that the alluvium formation has roughly uniform output between $9.39 \mathrm{~m}^{3} / \mathrm{h}, 11.23 \mathrm{~m}^{3} / \mathrm{h}$ and $23.38 \mathrm{~m}^{3} / \mathrm{h}$. Meanwhile in the fractured rock formation the efficiency was highly varied between sites, the highest is $32.33 \mathrm{~m}^{3} / \mathrm{h}$ and the other two sites obtained has low output of $3.44 \mathrm{~m}^{3} / \mathrm{h}$ and $1.00 \mathrm{~m}^{3} / \mathrm{h}$ respectively. The alluvium aquifer showed uniform water production compared to fractured hard rock aquifer. Meanwhile the water quantity in the fractured hard rock formation is unpredicted, which subjected to the fractured rock characteristic.
\end{abstract}

Keywords: Well pumping, aquifer, alluvium, fractured hard-rock

\section{Introduction}

Water supply-demand is increasing in line with the rise of population. Usable natural water resources are decreasing due to reduction of water catchment areas, river pollution, drought and illegal logging which causes the quantity and quality of raw water to decrease. Alternative water sources such as groundwater is able to reduce the scarcity of the natural water resource. Groundwater existed in aquifers either in the rock or soil formation is less 
polluted and may requires minimal water treatment. The aquifer can be categorized as either unconfined or confined. Unconfined aquifers are a layer of water-bearing formations or rocks that do not have a confining bed at the groundwater, referred to as the groundwater table, where the pressure becomes equivalent to the atmospheric pressure [1]. Confined aquifers are isolated from the ground surface by overlying aquitard layers, which is poorly permeable layer that limits the flow of groundwater from one aquifer to another [2]. Groundwater can be extracted via drilling tube well into the aquifer zone. Tube well designed is based on the type of soil and fractured rock that observed during the tube well drilling. A hydrogeological study of the subsurface water-bearing is performed via pumping test to identify transmissivity $(\mathrm{T})$, hydraulic conductivity $(\mathrm{K})$, and efficiency of the aquifer [3]. The pumping test is conducted to measure the amount of water from an aquifer. There are three stages of pumping tests that are performed, i.e., stepdrawdown, constant rate and recovery test. Step-drawdown test is conducted to determine the tube well output characteristics such as loss and the well efficiency through a series of constant pumping rate test. Constant pumping rate test intends to estimate the aquifer properties via maintaining the output of the aquifer. Recovery test is conducted to measure the rate of water level increment after constant pumping test is terminated.

In general, an aquifer within the unconsolidated sediments is considered as alluvium formation. The alluvium formation is younger in aged compared to fractured rock formation. The alluvium aquifer consists of loose sand and gravel that are influenced by above surface water. The advantages of alluvium aquifers are their abundant yields at shallow depth [4]. The fractured rock aquifer on the other hand can be found in the fractured zone of faults, joints and bedding planes of the rock mass. Water availability is primarily based on size and depth of the fracture openings, fracture spacing, the interconnection of fractures, and the source of recharge [5]. Alluvium aquifer is the most productive aquifer, with a yield of 50 to $100 \mathrm{~m} 3 / \mathrm{h} /$ well, while fractured rock aquifer most productive in limestone, with an output up to $50 \mathrm{~m} 3 / \mathrm{h} /$ well [6]. With this data, it can be concluded that the alluvium aquifer is more productive compared to the fractured rock aquifer.

The groundwater is preserved within the geological formations i.e., in the alluvium and hard-rock aquifers. The groundwater yield of each formation is unknown unless a pumping tests via drilling is conducted. Both types of aquifers have unique features in their abilities to produce water. In this study, the yield for both aquifers are identified by conducting a pumping test. It is crucial to predict the yield for each well at different geological formation for feasibility study purposes, i.e. to convince the client of the cost and outcome of the project. The study are conducted at three different locations of alluvium and fractured rock formations to determine the transmissivity and hydraulic conductivity of tube wells. Three different sites with alluvium aquifer formations were selected to conduct the pumping test namely IBS Universiti Malaysia Kelantan (UMK), Sekolah Kebangsaan Chantum and Sekolah Menengah Kebangsaan Agama Tok Bachok. These three alluvium formation sites are in the same district of Bachok Kelantan. The fractured rock aquifers are tested at IBS Universiti Malaysia, Kg. Dada Kering, and Kg. Seri Gunung Pulai which are located at Terengganu, Pahang and Johor respectively.

\section{Material and Method}

A pumping test is a method used to evaluate the performance of a well. The fundamental of a pumping test is by pumping water out from the well, thus lowering the water level [7,8]. There are three main stages of the pumping test. The first step is the drawdown test which was used to determine well loss, well efficiency and to identify well behaviour. The drawdown within the pumping well is affected by the portion of aquifer loss (BQ) and well loss component $\left(\mathrm{CQ}^{\mathrm{n}}\right)$, with $\mathrm{n}$ as the exponent of well loss [9]. Drawdown that occurs at the face of the well is known as aquifer loss, while drawdown that happens as water passes through the well screen and inside the well to the pump suction area is known as well loss. The coefficient of well loss, C, is controlled by well radius and well condition. The step drawdown test is designed with four to five steps, each step period between one and two hours. Fauzie et al. [9] stated that the step drawdown test was started at the low designed water capacity from $25 \%$ and increased to $50 \%$, $70 \%$, $100 \%$, and $125 \%$. The measured data were time and water level discharge during the test. The step drawdown test is to estimate the maximum yield of the well [8]. Secondly, the test are constant rate test (CRT) adopted to evaluate a fractured or porous formation [10]. Constant-rate tests are usually interpreted by evaluating the drawdown time series of 24 to 72 hours, subject to the yield capacity of the well [11]. The last stage are the recovery test, Trabucchi et al. [12] stated that the recovery tests consist of measuring water head reaction following the termination of constant rate test pumping. The water level in the well is beginning to increase after the water extraction has been shut down. The water head rises can be measured in what is known as the recovery test. The water level recovery test data is more reliable than drawdown data because the water table recovers at a constant rate [13]. Three sites at alluvium aquifer were selected to conduct the pumping test (IBS Universiti Malaysia Kelantan (UMK), Sekolah Kebangsaan Chantum and Sekolah Menengah Kebangsaan Agama Tok Bachok). These three sites are within the same district of Bachok, Kelantan. Table 1 shows the detailed tube well designed at alluvium test sites. Table 2 shows the detailed tube well designed at the fractured rock aquifer ( FRU Wakaf Tapai, Kg. Dada Kering and Kg. Seri Gunung Pulai). 
Table 1 - Alluvium aquifer tube well design

\begin{tabular}{cc}
\hline Site & Element \\
\hline $\begin{array}{c}\text { IBS Universiti Malaysia } \\
\text { Kelantan }\end{array}$ & Well Depth: $50 \mathrm{~m}$ \\
Depth of pump: $25 \mathrm{~m}$ \\
Alluvium: sand to sandy clay \\
\hline $\begin{array}{c}\text { Sekolah Kebangsaan Chantum, } \\
\text { Kelantan }\end{array}$ & Well depth: $32 \mathrm{~m}$ \\
Depth of pump: $25 \mathrm{~m}$ \\
$\begin{array}{c}\text { Sekolah Kebangsaan Agama Tok } \\
\text { Bachok, Kelantan }\end{array}$ & Alluvium: Fine sand to clay \\
\hline
\end{tabular}

Table 2. Fractured rock aquifer tube well design

\begin{tabular}{cc}
\hline Site & Element \\
\hline $\begin{array}{c}\text { FRU Wakaf Tapai, } \\
\text { Terengganu }\end{array}$ & Depth of well: $41 \mathrm{~m}$ \\
& Depth of pump: $32.5 \mathrm{~m}$ \\
& Type of rock: Diorite \\
& Depth of Rock from a surface: $7.5 \mathrm{~meter}$ \\
\hline Kg. Dada Kering, Pahang & Depth of well: $62 \mathrm{~m}$ \\
& Depth of pump: $45 \mathrm{~m}$ \\
Kg. Seri Gunung Pulai, Johor & Type of rock: Green Schist \\
& Depth of rock from a surface: $18 \mathrm{~m}$ \\
\hline & Depth of well: $100 \mathrm{~m}$ \\
& Depth of pump: $51 \mathrm{~m}$ \\
& Type of rock: Rhyolite \\
& Depth of rock from a surface: $28 \mathrm{~m}$
\end{tabular}

\section{Result and Discussion}

\subsection{Step-drawdown Test}

The first step for the pumping test was a step-drawdown test. Each of the sites was used the same flow rate for each of the 5 phases, which were $1.614 \mathrm{~m}^{3} /$ hour, $2.819 \mathrm{~m}^{3} /$ hour, $4.532 \mathrm{~m}^{3} /$ hour, $6.533 \mathrm{~m}^{3} /$ hour, and $9.119 \mathrm{~m}^{3} / \mathrm{hour}$. The readings for a step-drawdown test took 5 hours non-stop with different flow rates. Each flow rate for the pumping test was taken in increments, with each stage taking 60 min continuously. The step-drawdown test plots the graph-specific drawdown against time to obtain the value of the linear well loss (B) and non-linear well loss (C), as shown in Table 3.By using the formula Copper and Jacob, $75 \%$ of efficiency was obtained for both alluvium and fractured hard rock formations by using Equation 1. Table 4 demonstrates different flow rate for each of the five phases for different location at the fractured hard rock aquifer. With varying flow rates, the readings for a step-drawdown test took 5 hours non-stop. Each flow rate was measured in increments for the pumping test continuously, with each stage lasting 60 minutes. The step-drawdown test, the value of the linear well loss, B, and non-linear well loss are also shown in Table 5 for the fractured hard rock aquifer.

$$
\operatorname{Efficiency}(75 \%)=\left(\frac{B Q}{\left(B Q+C Q^{2}\right)}\right)
$$


Table 3 - Step-Drawdown Test at alluvium formation

\begin{tabular}{lcccc}
\hline & IBS UMK & SK Chantum & SMKA Tok Bachok \\
\hline $\begin{array}{l}\text { Linear Well Loss, B } \\
\left(\mathbf{m i n} / \mathbf{m}^{\mathbf{2}}\right)\end{array}$ & 5.82 & 9.49 & 9.37 \\
$\begin{array}{l}\text { Non-Linear Well Loss, } \\
\mathbf{C}\left(\mathbf{m i n}^{\mathbf{2}} / \mathbf{m}^{\mathbf{5}}\right)\end{array}$ & 49.8 & 16.90 & 20.00 \\
$\begin{array}{l}\mathbf{7 5 \%} \text { of } \\
\left(\mathbf{m}^{\mathbf{3}} / \mathbf{h o u r}\right)\end{array}$ & efficiency & 23.38 & 11.23 & 9.39 \\
\hline
\end{tabular}

Table 4 - 5 phases flow rate of site for fractured hard rock aquifer

\begin{tabular}{|c|c|c|c|}
\hline & FRU Wakaf Tapai & Kg. Dada Kering & Kg. Seri Gunung Pulai \\
\hline Phase $1\left(\mathrm{~m}^{3} /\right.$ hour $)$ & 12.07 & 1.30 & 1.59 \\
\hline Phase $2\left(\mathbf{m}^{3} /\right.$ hour $)$ & 13.85 & 2.60 & 2.13 \\
\hline Phase $3\left(\mathrm{~m}^{3} /\right.$ hour $)$ & 15.71 & 3.90 & 2.77 \\
\hline Phase $4\left(\mathrm{~m}^{3} /\right.$ hour $)$ & 17.76 & 5.20 & 3.53 \\
\hline Phase $5\left(\mathrm{~m}^{3} /\right.$ hour $)$ & 19.94 & 6.50 & 4.38 \\
\hline
\end{tabular}

Table 5 - Step-Drawdown Test for fractured hard rock aquifer

\begin{tabular}{|c|c|c|c|}
\hline & FRU Wakaf Tapai & Kg. Dada Kering & Kg. Seri Gunung Pulai \\
\hline $\begin{array}{l}\text { Linear Well Loss, B } \\
\left(\mathrm{min} / \mathrm{m}^{2}\right)\end{array}$ & 7.37 & 88.50 & 161.00 \\
\hline $\begin{array}{l}\text { Non-Linear Well Loss, } \\
\mathrm{C}\left(\mathrm{min}^{2} / \mathrm{m}^{5}\right)\end{array}$ & 4.56 & 514.00 & 3230.00 \\
\hline $\begin{array}{l}75 \% \text { of } \\
\left(\mathrm{m}^{3} / \text { hour }\right)\end{array}$ & 32.33 & 3.44 & 1.00 \\
\hline
\end{tabular}

\subsection{Constant Rate Test}

A constant-rate test is used to determine the hydraulic parameters of an aquifer system. The test was conducted using the flow rate calculated from the step-drawdown test. The data tabulated in Table 6 shows the value of transmitivity and hydraulic conductivity for alluvium aquifer formations. The transmitivity of IBS UMK was the highest at $65.8 \mathrm{~m}^{2} / \mathrm{hr}$, and the lowest was SK Chantum which is $11.20 \mathrm{~m}^{2} / \mathrm{hr}$. Meanwhile, for hydraulic conductivity, the highest was SMKA Tok Bachok which was $1.34 \mathrm{~m} /$ hour, and the lowest was SK Chantum with $0.35 \mathrm{~m} / \mathrm{hr}$. For fractured hard rock aquifer formations, the transmitivity and hydraulic conductivity data are showed in Table 7. The highest transmitivity and hydraulic conductivity are both obtained at FRU Wakaf Tapai, with $7.08 \mathrm{~m}^{2} / \mathrm{hr}$ and $0.17 \mathrm{~m} / \mathrm{hr}$, respectively. The lowest are located at borehole at $\mathrm{Kg}$. Seri Gunung Pulai which has transmitivity and hydraulic conductivity of $0.023 \mathrm{~m}^{2} / \mathrm{hr}$ and $0.00023 \mathrm{~m} / \mathrm{hr}$ respectively.

Table 6 - Transmitivity and Hydraulic Conductivity of alluvium aquifer

\begin{tabular}{lccc}
\hline & IBS UMK & SK Chantum & SMKA Tok Bachok \\
\hline Flow Rate $\left(\mathbf{m}^{\mathbf{3}} / \mathbf{h r}\right)$ & 23.38 & 11.23 & 9.39 \\
$\begin{array}{l}\text { Transmitivity }\left(\mathbf{m}^{\mathbf{2}} / \mathbf{h r}\right) \\
\begin{array}{l}\text { Hydraulic Conductivity } \\
\text { (m/hour) }\end{array}\end{array}$ & 65.8 & 11.20 & 49.6 \\
\hline
\end{tabular}


Table 7 - Transmitivity and hydraulic conductivity of fractured hard rock aquifer

\begin{tabular}{lccc}
\hline & FRU Wakaf Tapai & Kg. Dada Kering & Kg. Seri Gunung Pulai \\
\hline Flow Rate $\left(\mathbf{m}^{\mathbf{3}} / \mathbf{h r}\right)$ & 32.33 & 11.23 & 9.39 \\
Transmitivity $\left(\mathbf{m}^{\mathbf{2}} / \mathbf{h r}\right)$ & 7.08 & 0.15 & 0.023 \\
$\begin{array}{l}\text { Hydraulic conductivity } \\
(\mathbf{m} / \mathbf{h r})\end{array}$ & 0.173 & 0.002 & 0.00023 \\
\hline
\end{tabular}

\subsection{Recovery Test}

A recovery test was conducted at the end of a pumping test. After the constant rate test was taken, the time taken for the water level to recover was tabulated in Table 8 and Table 9 for alluvium aquifer and fractured hard rock aquifer, respectively. The optimum result of the recovery test is obtained by allowing the water level to reach at least 75 percent of the initial static water level. Both Table 8 and Table 9 shows the pre-pumping static water level, water level after a recovery test, the time taken for water level recover, and percentage of the recovery. The calculation method for the rate of water recovery results in the tube well is by pre-pumping static water level divided by the static water level after recovery test and multiplied by $100 \%$. Table 8 shows the recovery test result of all the boreholes located at the alluvium aquifer. The time taken in SK Chantum was the highest by 840minutes, and the lowest was SMKA Tok Bachok, by 60minutes. Meanwhile, for the percentage of recovery, the highest was at IBS UMK which was $99.29 \%$, and the lowest was SK Chantum with $92.67 \%$. Table 9 shows the flow rate of all the fractured hard rock aquifer boreholes. The time taken at Kg. Dada Kering was the highest at 1210minutes, and the lowest was at FRU Wakaf Tapai which was 160minutes. One boreholes that does not meet the established standards was located at Kg. Dada Kering. For the percentage of recovery, it is found that both FRU Wakaf Tapai and Kg. Seri Gunung Pulai have high percentage of recovery of $96.60 \%$ and $99.56 \%$ respectively.

Table 8 - Recovery test for alluvium aquifer

\begin{tabular}{lccc}
\hline & IBS UMK & SK Chantum & SMKA Tok Bachok \\
\hline $\begin{array}{l}\text { Pre-pumping Static } \\
\text { Water Level, (meter), }\end{array}$ & 4.25 & 4.30 & 4.55 \\
A & & & \\
$\begin{array}{l}\text { Static Water Level } \\
\text { after recovery test, } \\
\text { (meter), B }\end{array}$ & 4.28 & 4.64 & 4.59 \\
$\begin{array}{l}\text { Time taken for } \\
\text { recovery (min) }\end{array}$ & 540 & & \\
$\begin{array}{l}\text { Percentage of } \\
\text { recovery }(\%)= \\
(\mathbf{A} / \mathbf{B}) \mathbf{1 0 0}\end{array}$ & 99.29 & 840 & 60 \\
\hline
\end{tabular}

Table 9 - Recovery test for fractured hard rock aquifer

\begin{tabular}{lccc}
\hline & FRU Wakaf Tapai & Kg. Dada Kering & Kg. Seri Gunung Pulai \\
\hline $\begin{array}{l}\text { Pre-pumping Static } \\
\text { Water Level, (meter), A }\end{array}$ & 3.13 & 3.83 & 5.50 \\
$\begin{array}{l}\text { Static Water Level } \\
\text { after recovery test, } \\
\text { (meter), B }\end{array}$ & 3.24 & 5.60 & 5.53 \\
$\begin{array}{l}\text { Time taken for } \\
\text { recovery (min) }\end{array}$ & 160 & & \\
$\begin{array}{l}\text { Percentage of recovery } \\
(\%)=(\mathbf{A} / \mathbf{B}) \mathbf{1 0 0}\end{array}$ & 96.60 & 610 & 300 \\
\hline
\end{tabular}




\subsection{Discussions}

Table 10 and Table 11 shows the overall results of alluvium and fractured hard rock aquifer. These results details the ability of the aquifer to transmit groundwater throughout its entire saturated thickness which is referred to as transmitivity. Furthermore, hydraulic conductivity is vital in determining the rate of water flow in the aquifer. Finally, the tube well efficiency must follows the permitted well efficiency, which cannot be less than $75 \%$. The highest discharge rate from the alluvium aquifer was $23.38 \mathrm{~m}^{3} /$ hour at IBS UMK compared to the other two sites, $11.28 \mathrm{~m}^{3} / \mathrm{hour}$ for SK Chantum and $9.39 \mathrm{~m}^{3} /$ hours for SMKA Tok Bachok. It was found from alluvium formations that IBS UMK is a rich aquifer compared to the other sites based off the transmittivity, hydraulic conductivity and efficiency.

The soil texture is the primary determinant of the ease and speed of water moving through the soil and into the tube well. Coarse textured soils such as sands have large pore spaces between the soil particles, allowing water to percolate down to the groundwater entering the tube well quickly. There is minimal time in which filtration of the water can take place. Conversely, in fine-textured soils such as clays, water movement through the soil is very slow. It can be proven by the production of water in tube well at IBS UMK which was the highest because it has only two layers of sandy clay compared to SMKA Tok Bachok, which has six layers of sandy clay. Depth also affects the production of water in the tube well. Infiltration of water into the soil requires a long period of time to enter the tube well from the soil surface through the ground if the depth of the tube well is too deep. However, the most efficient tube well does not necessarily produce the highest productive tube well. The well efficiency evaluates how much loss influences the pumping well's drawdown. The well is the most efficient if there is no well loss, and the drawdown in the pumping well is only affected by aquifer loss. For fractured hard rock, the highest discharge is $32.33 \mathrm{~m}^{3} /$ hours at FRU Wakaf Tapai, followed by Kg. Dada Kering and Kg. Seri Gunung Pulai with $3.44 \mathrm{~m}^{3} /$ hour and $1.00 \mathrm{~m}^{3} /$ hour, respectively. It was found that from the rhyolite rock type in $\mathrm{Kg}$. Seri Gunung Pulai and greenschist in Kg Dada Kering that the two boreholes on the fractured hard rocks are relatively very poor aquifers. The factor influencing the result is the depth of the rock from the earth's surface. The infiltration rate from the earth's surface to reach the rock area takes a short time if the depth is shallow. The shallowest depth is at FRU Wakaf Tapai, which is only 7.5 meters compared to the other sites of 18 and 28 meters.

From the observed boreholes, it can be conclude that alluvium aquifer is more effective in efficiency, transmitivity, and hydraulic conductivity compared to the fractured hard rock aquifer. However, under certain circumstances, fractured hard rock can be a better aquifers. Various factors may influenced the quality of the aquifers such as weather or depth of rock from the ground surface. Further studies are needed to identify other factors that affect the flow rate of water in the tube well.

Table 10 - Alluvium aquifer overall data

\begin{tabular}{lccc}
\hline & IBS UMK & SK Chantum & SMKA Tok Bachok \\
\hline Type of Alluvium & $\begin{array}{l}\text { Three-layer of sand } \\
\text { cover up to two } \\
\text { layers of sandy clay }\end{array}$ & $\begin{array}{l}\text { One layer of a fine } \\
\text { sand cover-up of } 3 \\
\text { layers of clay }\end{array}$ & $\begin{array}{l}\text { Six layers of sand cover } \\
\text { up to six layers of sandy } \\
\text { clay }\end{array}$ \\
Transmitivity $\left(\mathbf{m}^{\mathbf{2} / \mathbf{h})}\right.$ & 65.8 & 11.2 & 49.6 \\
$\begin{array}{l}\text { Hydraulic Conductivity } \\
(\mathbf{m} / \mathbf{h})\end{array}$ & 1.32 & 0.35 & 1.34 \\
$\begin{array}{l}\text { Efficiency for } \mathbf{7 5 \%} \\
\left(\mathbf{m}^{\mathbf{3}} / \mathbf{h}\right)\end{array}$ & 23.38 & 11.23 & 9.39 \\
\hline
\end{tabular}

Table 11 - Fractured hard rock aquifer overall data

\begin{tabular}{lccc}
\hline & FRU Wakaf Tapai & Kg. Dada Kering & Kg. Seri Gunung Pulai \\
\hline Type of Hard Rock & Diorite & Green Schist & Rhyolite \\
Transmitivity $\left(\mathbf{m}^{\mathbf{2}} / \mathbf{h}\right)$ & 7.08 & 0.15 & 0.023 \\
$\begin{array}{l}\text { Hydraulic Conductivity } \\
(\mathbf{m} / \mathbf{h})\end{array}$ & 0.173 & 0.002 & 0.00023 \\
Efficiency for $\mathbf{7 5 \%}\left(\mathbf{m}^{\mathbf{3}} \mathbf{h}\right)$ & 32.33 & 3.44 & 1.00 \\
\hline
\end{tabular}




\section{Conclusions}

The study has conducted tube well pumping tests at two different geological formation of alluvium and fractured hard rock formation.. Two hydraulic parameters data were obtained at both geological formations, specifically transmitivity and hydraulic conductivity. The transmitivity at alluvium aquifer were $65.8 \mathrm{~m}^{2} / \mathrm{h}, 11.2 \mathrm{~m}^{2} / \mathrm{h}$ and $49.6 \mathrm{~m}^{2} / \mathrm{h}$. Meanwhile for fractured hard rock aquifer,the transmitivity were $7.08 \mathrm{~m}^{2} / \mathrm{h}, 0.15 \mathrm{~m}^{2} / \mathrm{h}$, and $0.023 \mathrm{~m}^{2} / \mathrm{h}$. For hydraulic conductivity, the alluvium formations produced $1.32 \mathrm{~m} / \mathrm{h}, 0.35 \mathrm{~m} / \mathrm{h}$ and $1.34 \mathrm{~m} / \mathrm{h}$. The fractured hard rock aquifer however only produced $0.173 \mathrm{~m} / \mathrm{hr}, 0.002 \mathrm{~m} / \mathrm{hr}$, and $0.00023 \mathrm{~m} / \mathrm{hr}$. The tube well efficiency from the aquifer refers to data on $75 \%$ efficiency on two different site formations, For the alluvium formations, the well efficiency were $23.38 \mathrm{~m}^{3} / \mathrm{h}, 11.23 \mathrm{~m}^{3} / \mathrm{h}, 9.39 \mathrm{~m} 3 / \mathrm{h}$. Whilts for the fractured hard rock formations the well efficiencty were $32.33 \mathrm{~m}^{3} / \mathrm{h}$, $3.44 \mathrm{~m} 3 / \mathrm{h}$, and $1.00 \mathrm{~m}^{3} / \mathrm{h}$, respectively. From the obtained data, it can be summarized that ideally the alluvium aquifer are used for water production by using tube wells. Alluvium aquifer showed uniform water production compared to fractured hard rock. However, tubewell on fractured hard rock formations may also produce more water compared to the alluvium formation but this largely depends on the depth of the well and the soil texture. It is also suggested when conducting the pumping test, suitable pump are used based on the capacity of the production of the tube well and the position of the pump are not positioned at the well screen area to avoid turbulence flow in the tube well.

\section{Acknowledgement}

The authors would like to acknowledge the Faculty of Civil Engineering and Built Environment, Universiti Tun Hussien Onn Malaysia, Parit Raja, Batu Pahat, Johor, Geoscience Department, Faculty of Earth Science, Universiti Malaysia Kelantan, Jeli, Kelantan and National University of Sciences and Technology Pakistan, Islamabad, Pakistan.

\section{References}

[1] Kerkeni, L., Ruano P., Delgado L., L. Picco, S. Villegas, L. Tonelli, F. Merlo, M. Rigau, J. Diaz, D. \& Masuelli M. 2016. Intech Open. Characteristics and Assessment of Groundwater

[2] Alley. 2010. Fractured Rock and Confined Aquifers

[3] D. Dean. 2015. Faculty of the Department of Geology. The Hydraulic Conductivity Of The Shallow WaterBearing Interval And The Hydraulic Conductivity, Transmissivity, Storativity of The Deep WaterBearing Interval Beneath Csus Campus. (California State University)

[4] Jean, C. Prior. 2004. Alluvial Aquifers of Iowa. Iowa (Dept. of Natural Resources, Iowa Geological Survey Educational) Series 683

[5] John K. 2016. Groundwater in Fractured Rock Aquifers Well Location, Yield, and Sustainability.

[6] Department of Mineral and Geoscience Malaysia. 2019. Groundwater Overview in Malaysia. In National Groundwater Conference 2019

[7] Charly, V., Sujatmoko, B., \& Shandyavitri, A. 2017. Jurnal Online Mahasiswa (JOM) Analisis Karakteristik Hidraulis Air Tanah Gambut berdasarkan Uji Pemompaan. 4(1). pp 1-9

[8] Bolton, W. 2011. Computers and the Humanities. Technical review. 28(3). pp 191-198

[9] Fauzie, M. J., Azwan, M. M. Z., Hasfalina, C. M., \& Mohammed, T. A. 2014. Performanceevaluation and characteristics of selected tube wells in the coastal alluvium aquifer, Selangor. Pertanika Journal of Science and Technology. 22(1) 225-238

[10] Ming-Ming, L., Yi-Feng, C., Jia-Min, H., \& Chuang-Bing, Z. 2016. Water Resources Research. Journal of the American Water Resources Association. 5(3) 2-2

[11] Ferroud, A., Chesnaux, R., \& Rafini, S. 2019. Hydrogeology Journal drawdown log-derived analysis for interpreting constant-rate pumping tests in inclined substratum aquifers. 27(6) 2279-2297

[12] Trabucchi, M. Carrera, J., \& Fernàndez-Garcia, D. 2018. Water Resources Research. Generalizing Agarwal's Method for the Interpretation of Recovery Tests Under Non-Ideal Conditions. 54(9) 6393-6407

[13] Kruseman, G. P., \& Ridder, N. A. de. 2000. Journal of Hydrology. Analysis and evaluation of pumping test data and: Bulletin 11. (International Institute for Land Reclamation and Improvement, Wageningen, the Netherlands) 12(3) 281-282 